\title{
Comparing the evacuation speed through a ramp and a stair in a tsunami evacuation drill in Padang
}

\author{
Badrul M. Kemal ${ }^{1}$ and Yosritzal ${ }^{1 *}$ \\ ${ }^{1}$ Department of Civil Engineering, Andalas University, Padang, Indonesia
}

\begin{abstract}
In a vertical evacuation, there are two types of a route that could be chosen namely a ramp and a stair. A ramp is usually used to help a disabled person with a wheelchair to reach the top of a shelter and a stair is used for normal persons. However, in an evacuation, speed is very important. Therefore, a comparison between the use of stairs and ramp in terms of evacuation speed to reach the top should be evaluated. This paper presents an evaluation of the evacuation speed using stairs and ramps by normal persons. The study found that evacuating using stairs is slightly faster than using a ramp.
\end{abstract}

\section{Introduction}

Many authors reported that Padang City, the capital of West Sumatera Province, Indonesia, has a significant tsunami hazard potential as the city is located close to the Mentawai megathrust at the West Coast of Sumatera Island $[1,4]$. The Mentawai megathrust which has two segments, namely the Siberut segment and the SiporaPagai segment, has a strong earthquake cycle of 200-300 years. The biggest threat today is the earthquake cycle from the Siberut segment which can cause a tsunami. Fig. 1 shows several major earthquake events around the megathrust site [5].

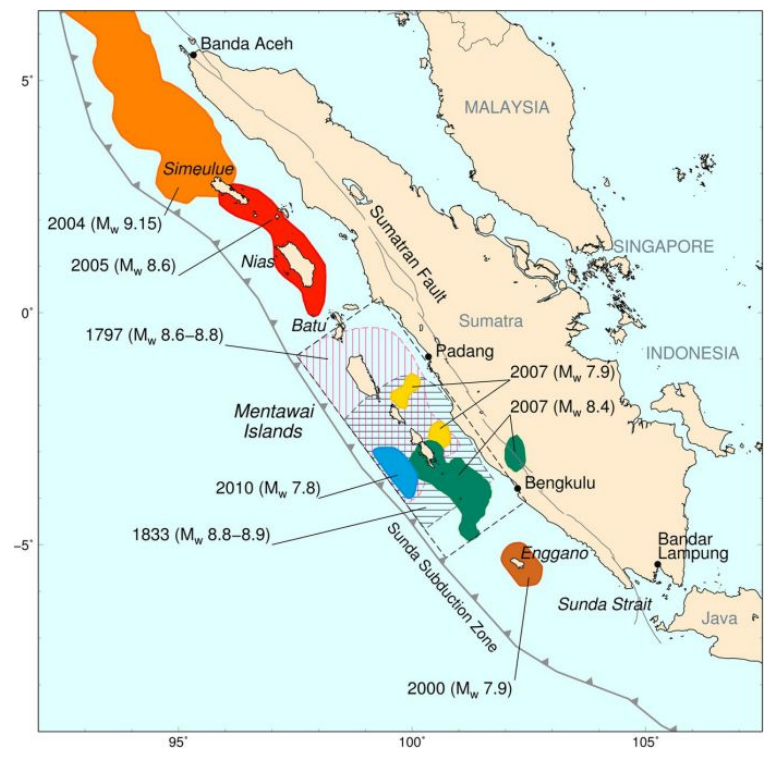

Fig. 1. Historical recent seismic activities in the Sumatra areas [5].

\footnotetext{
* corresponding author: yosritzal@eng.unand.ac.id
}

About half of the Padang City population are living in a tsunami-prone area with an altitude less than $5 \mathrm{~m}$ above sea level [6]. As the city is located near to the Ring of Fire at the West Part of Sumatera Island, the city has been hit repetitively by many big earthquakes with some of them triggering significant tsunamis to the west coastal area of Sumatera Island and nearest islands such as Mentawai and Nias Islands. McCloskey [3] reported that on February 10, 1797, and November 24, 1833, two earthquakes triggered a tsunami of $5 \mathrm{~m}$ and 3-4 m inundation high respectively. Furthermore, McCloskey and other scientists also predicted a huge seismic moment deficit accumulation since 1797 and 1833 at the megathrust which was predicted to trigger a $15 \mathrm{~m}$ tsunami inundation in Padang in the near future $[3,6,7$, 8].

The Indonesian Government with help of many countries and universities has made some progress in applying disaster mitigation systems such as developing tsunami early warning systems, increasing the capacity of tsunami evacuation routes, preparing some temporary evacuation sites and shelters, increasing the road capacity along the evacuation routes and educating people about tsunami and evacuation [9, 10]. However, many contributions are still demanded to reduce the risk and impact of the earthquake and tsunami before the predicted event becomes a reality. This paper contributes to preparing the evacuation mitigation by evaluating and comparing the evacuation speed using a ramp and a stair.

An understanding of the walking speed during an evacuation has an important role in developing evacuation plans $[11,13]$. However, the estimation of walking speed in the previous studies was not based on a specific observation for evacuation but based on the 
observation of some short-distance crosswalks (such as [14]). Yosritzal [6] was among the first to assess the walking speed during an evacuation and found that the walking speed varies by age and gender. The study was extended to assess the role of route complexity and duration of the walking in [15]. Yosritzal found that the walking speed tends to be slower at the end section of the evacuation route because of fatigue [15]. The finding of the study triggered a question: could the evacuees reach the top floor of the tsunami shelter before the tsunami wave arrives after walking from more than $1 \mathrm{~km}$ away? Comparing the stairs and the ramp, which one is the fastest way to reach the top floor? This will be answered in this paper.

The presented paper aims to compare walking speed during a simulated tsunami evacuation event by using a stair and a ramp after walking more than $1 \mathrm{~km}$. The observed evacuation distance of the route in the simulation was set to be equal to the estimated evacuation distance based on the effective evacuation time from [9]. The special contribution of this paper was integration between horizontal evacuation from home to a shelter and vertical evacuation from the ground of the shelter building to the top of the building either through a ramp or a stair. This paper is an extension of our previous study which observed the walking speed of evacuees during an experiment of tsunami evacuation in Padang [15].

\section{Literature Review}

\subsection{The feature of Research Site}

This study was taken place at Padang City, the capital city of West Sumatera Province, Indonesia. The city is located between $0^{\circ} 44^{\prime}$ and $01^{\circ} 08^{\prime}$ South Latitude and $100^{\circ} 05^{\prime}$ and $100034^{\prime}$ East Longitude [16]. The city's terrain is almost flat at no more than five meters above sea level, which extends about $4 \mathrm{~km}$ from the coast before climbing the hills further inland. The research site is shown in Fig. 2.

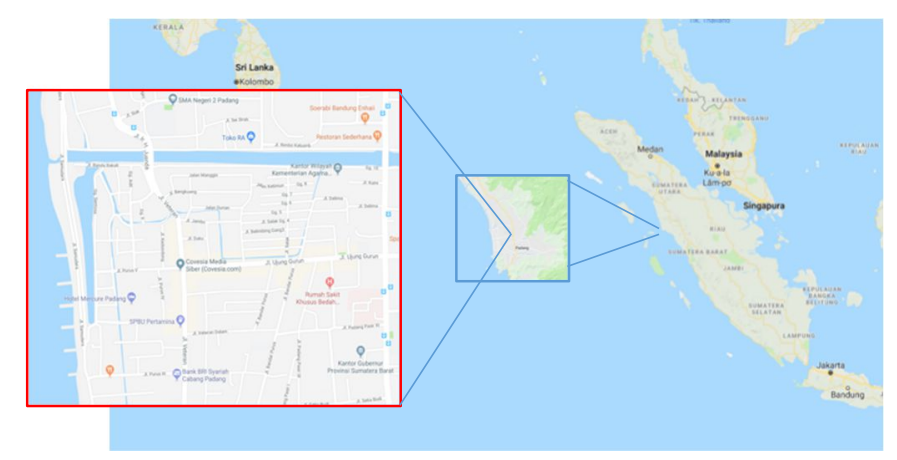

Fig. 2. Case Study Location in Padang City [6][15]

Yosritzal estimated the effective evacuation time for the people in Padang is about 17 minutes which is equivalent to around $1.4 \mathrm{~km}$ distance [9]. As the evacuation time is very short, it was suggested that the evacuation should be made on foot and immediately after the earthquake [17], bringing their emergency bag to the nearest shelter or the safety zones [18]. Using cars are not recommended during evacuation as it would make evacuation more difficult due to traffic jam and bottleneck [19]. This has been proven as a 7.3 SR earthquake hit Mentawai Island on March 2, 2016, majority of the evacuations were made by cars but none of them could pass through the traffic and reach the safety zone within the available evacuation time, fortunately, no tsunami occurred at the time (see [20]). This phenomenon also emerged in an agent-based model developed by Muhammad et al. (2021) and as a solution, they suggested adding more evacuation points easily accessible without a motor vehicle so that the evacuation would be more efficient.

\subsection{Walking Speed Studies in Disaster Evacuation}

In traffic engineering, study on walking speed is required in designing pedestrian facilities such as crosswalks and timing for traffic light operation therefore the data is commonly observed from a simulation of pedestrian movement in a corridor, sidewalk or crosswalk $[22,26]$. The average walking time from those studies was used by several studies to estimate the coverage area and demand of a shelter such as in $[9,10,27]$. Abustan used average walking speed at a crosswalk as a parameter in a tsunami evacuation simulation[28]. Wood pointed that the decision to start evacuation is playing an important role in determining the minimum travel speed to evacuate from hazard zone [29].

Arguing that the normal walking speed might not be similar to the evacuation speed, Yosritzal conducted a tsunami evacuation simulation to estimate the walking speed during evacuation [60. Based on [6], Chasanah and Sakakibara used $1.4 \mathrm{~m} / \mathrm{s}$ as the evacuation walking speed in the study on the volcanic eruption's evacuation case [30]. Similarly, [31] set walking speed into three categories namely slow $(1.35 \mathrm{~m} / \mathrm{s})$, medium $(1.4 \mathrm{~m} / \mathrm{s})$ and fast $(1.51 \mathrm{~m} / \mathrm{s})$ based on [6].

In a previous study, the variation of the walking speed was observed by age and by gender [6, 28, 29]. Yosritzal suggested adding the duration of the walk and the complexity of the route as a determinant of the walking speed [15]. Yosritzal developed three scenarios in the evacuation drill which were based on the complexity of the route [15]. The complexity of the route was simplified by assuming the more turning points along the route, the more complex the route. The result shows that walking speed was not constant along the evacuation route. The walking speed tended to be slower as the distance is increasing [15] which is expected to be caused by the fatigue experienced by the evacuees.

\section{Methodology}

Similar to the previous study in [6] and [15], in this presented study, the walking speed was observed from 
an evacuation drill from a specified point inside the residential area to the rooftop of the Temporary Evacuation Site (TES) next to the West Sumatera Governor's Office, at Soedirman Road. The route of evacuation is shown in Fig. 3. Observers were placed at 6 important points along the routes to observe the time when the Evacuees pass through their position. The first four observers were placed along the evacuation road and one observer at the rooftop of the TES. The volunteers were asked to walk fast from the specified point to the specified point at the rooftop. The timing data recorded by the observers will be analyzed to achieve the objective of the study.

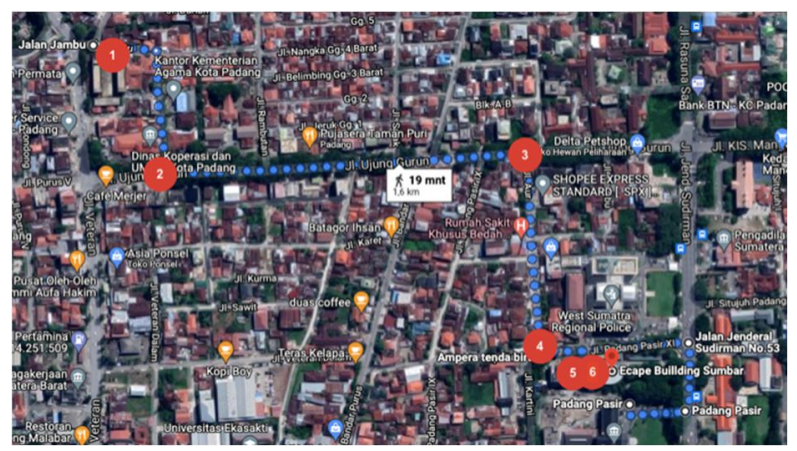

Fig. 3. The route of the evacuation drill (captured from Google map)

The evacuation drill was conducted on July 14, 2018. The starting point was at the residential area about $1.07 \mathrm{~km}$ from the TES and then climbing to the rooftop of the TES through a ramp or a stair. The volunteers were categorized into 5 groups namely: 10-20-year-old, 21-30 year old, 31-40-year-old, 41-50-year-old, and more than 50-year-old. There were three volunteers in each group. There were four scenarios in the study:

a. One by one volunteer take turns to evacuate from the original point to the destination through a specified route and climb the TES through the stair.

b. All volunteers at the same age interval group simultaneously evacuate from the original point to the destination through a specified route and climb the TES through the stair.

c. One by one by volunteers take turns to evacuate from the original point to the destination through a specified route and climb the TES through the ramp.

d. All volunteers at the same age interval group simultaneously evacuate from the original point to the destination through a specified route and climb the TES through the ramp.

The mean of observed walking speed by each age group, one by one or simultaneously, and by stair or ramp will be compared. The conclusion and recommendation will be made based on those comparisons.

The detail of the simulation segments is shown in Table 1. Segment 1 is located in the residential area and rarely to find a car or people walking as most of the people enjoy staying at home with family during the weekend. Segment 2 is located at the main road with an up to $2.5 \mathrm{~m}$ sidewalk on both sides of the road. Segment 3 is a busy road as many activities are available here such as a hospital, shops, and offices. A lot of cars are parked on both sides of the road. No proper sidewalk is available on this road. Segment 4 is relatively quiet on the weekend. Segment 5 is the segment where evacuees started to climb the TES either through stairs or a ramp.

Table 1. Detail Simulation Evacuation Route

\begin{tabular}{|c|c|c|c|c|}
\hline \multirow{2}{*}{ Route } & \multicolumn{2}{|c|}{ Road + Stairs } & \multicolumn{2}{c|}{ Road + Ramp } \\
\cline { 2 - 5 } & $\begin{array}{c}\text { Distanc } \\
\text { e (m) }\end{array}$ & $\begin{array}{c}\text { Route } \\
\text { Wide } \\
\text { (m) }\end{array}$ & $\begin{array}{c}\text { Distanc } \\
\text { e (m) }\end{array}$ & $\begin{array}{c}\text { Route } \\
\text { Wide } \\
\text { (m) }\end{array}$ \\
\hline $\begin{array}{c}\text { Segment I } \\
\text { Origin (point } \\
\text { 1) to point 2 }\end{array}$ & 200 & 4 & 200 & 4 \\
\hline $\begin{array}{c}\text { Segment II } \\
\text { Point 2 to } \\
\text { point 3 }\end{array}$ & 457,6 & 7 & 457,6 & 7 \\
\hline $\begin{array}{c}\text { Segment III } \\
\text { Point 3 to } \\
\text { point 4 }\end{array}$ & 248,1 & 7 & 248,1 & 7 \\
\hline $\begin{array}{c}\text { Segment IV } \\
\text { Point 4 to } \\
\text { point 5 } \\
\text { (ground) }\end{array}$ & 296,9 & 7 and & 320 & 7 and 4 \\
\hline $\begin{array}{c}\text { Segment V } \\
\text { Point 5 } \\
\text { (ground) to } \\
\text { point 5 } \\
\text { (rooftop) }\end{array}$ & 39,24 & 1,8 & 173,5 & 2,9 \\
\hline
\end{tabular}

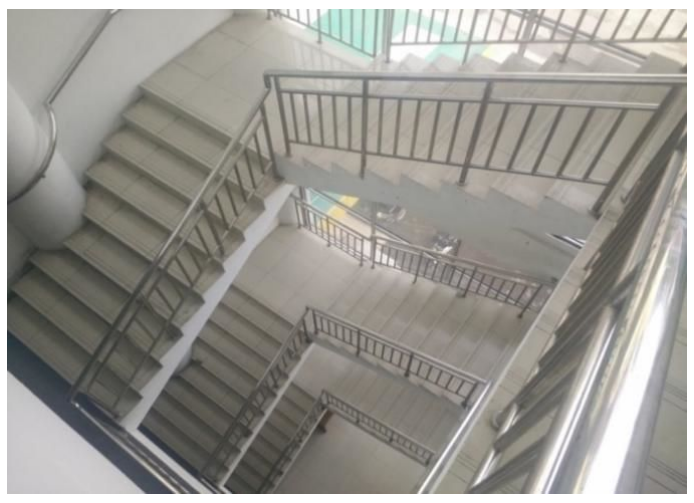

( a ) Stairs

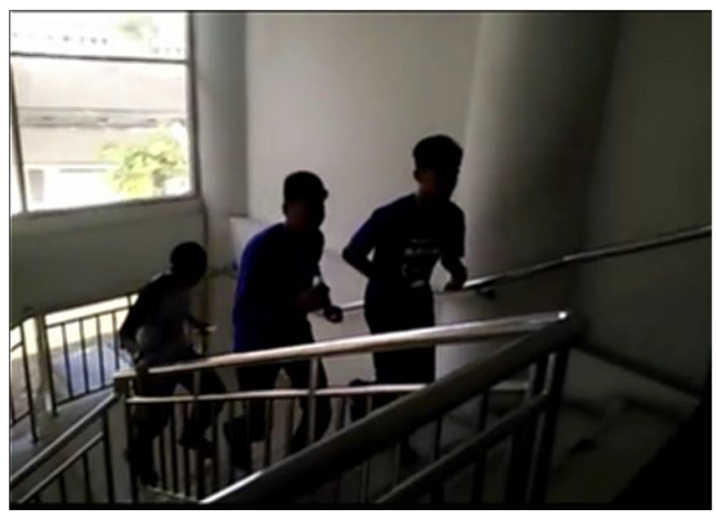

( b ) Situation during the evacuation drill through stairs 


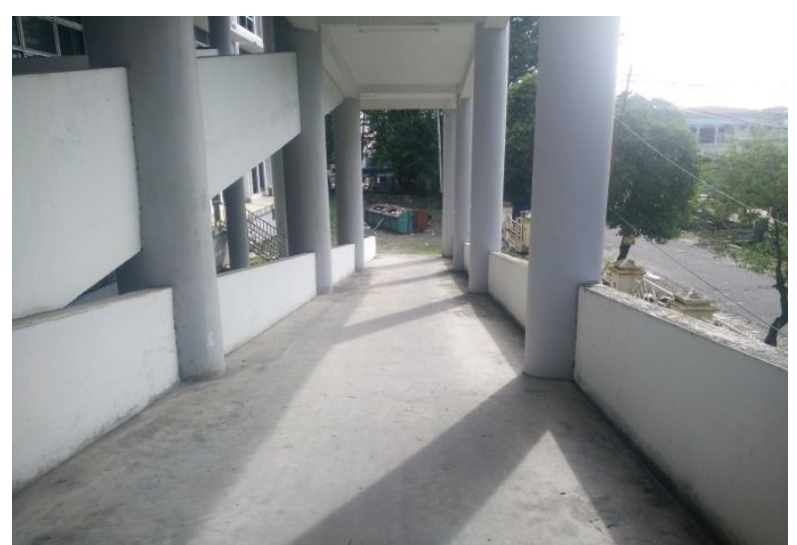

( c ) Ramp

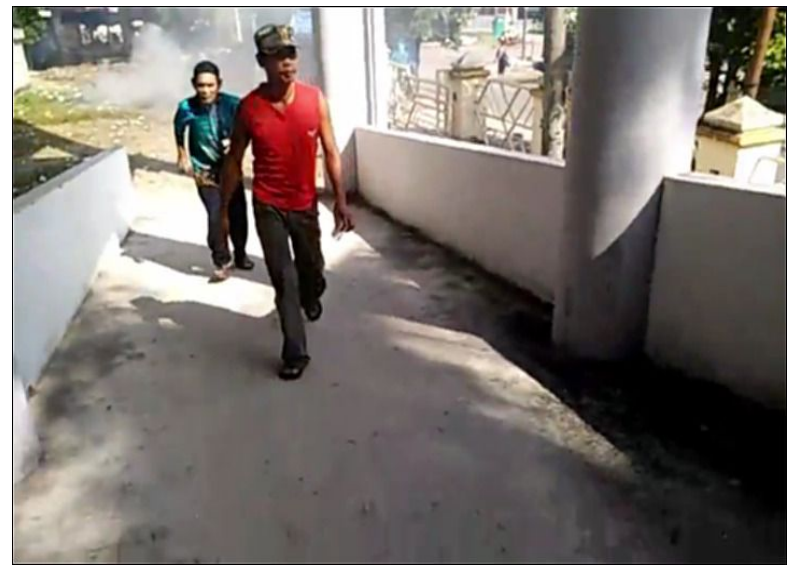

( d ) Situation during the evacuation drill through the ramp

Fig.4. The sites and situations of evacuation drills through stairs and Ramp from the ground to the rooftop

The picture of the stairs and ramp are shown in Figure 4. In this study, the slope of the ramp and stairs were not considered as a variable in the analysis. The only variable considered was the time and the distance from the ground to the rooftop of the TES building. The dimension of the stairs and ramp were neglected as the number of samples is low. These pre-judgments are debatable but, in this study, we limit the study within the scope of those assumptions.

The evacuation drills took place in the morning and no electric bulb is on, so the light source is only from the sun. As the stairs are located inside and the ramp is in the outside of the TES building, the stairs are relatively darker than the ramp. However, the low light does not significantly influence the walking speed as the stairs and the situation around the stairs are still clearly visible by normal eyes.

\section{Results}

\subsection{Stairs}

Walking from the origin point to the destination point at the rooftop of the TES using stairs will take time as shown in Table 2.
Tabel 2. Walking Time Through Stairs by Age Interval Group in Second

\begin{tabular}{|c|c|c|c|c|c|c|c|}
\hline \multirow{2}{*}{$\begin{array}{c}\text { Chec } \\
\text { k } \\
\text { Point }\end{array}$} & \multirow[b]{2}{*}{$\begin{array}{l}\text { Distan } \\
\text { ce }(\mathrm{m})\end{array}$} & \multicolumn{6}{|c|}{$\begin{array}{c}\text { Walking Time by Age Group Interval } \\
\text { (Second) }\end{array}$} \\
\hline & & $\begin{array}{c}11- \\
20 \\
\text { y.o. }\end{array}$ & $\begin{array}{c}21- \\
30 \\
\text { y.o. }\end{array}$ & $\begin{array}{c}31- \\
40 \\
\text { y.o. }\end{array}$ & $\begin{array}{c}41- \\
50 \\
\text { y.o. }\end{array}$ & $\begin{array}{l}>\mathbf{5 0} \\
\text { y.o. }\end{array}$ & Av. \\
\hline $1-2$ & 200.0 & 100 & 160 & 80 & 80 & 120 & 108 \\
\hline $2-3$ & 457.0 & 220 & 240 & 300 & 260 & 260 & 256 \\
\hline $3-4$ & 248.0 & 60 & 60 & 180 & 140 & 160 & 120 \\
\hline $4-5$ & 297.0 & 220 & 180 & 220 & 180 & 180 & 196 \\
\hline $5-6$ & 40.4 & 60 & 60 & 60 & 80 & 180 & 88 \\
\hline Total & 1242.4 & & & & & & \\
\hline
\end{tabular}

Fig. 5. shows the walking speed of the evacuees from the origin point through the evacuation route to the destination point (rooftop of the TES) through the available stairs. Fig. 5. shows that the walking speed is reduced by the distances except for the case of evacuees in the age group of 21-30 and 11-20 years old. The walking speed was reduced to around $1 \mathrm{~m} / \mathrm{s}$.

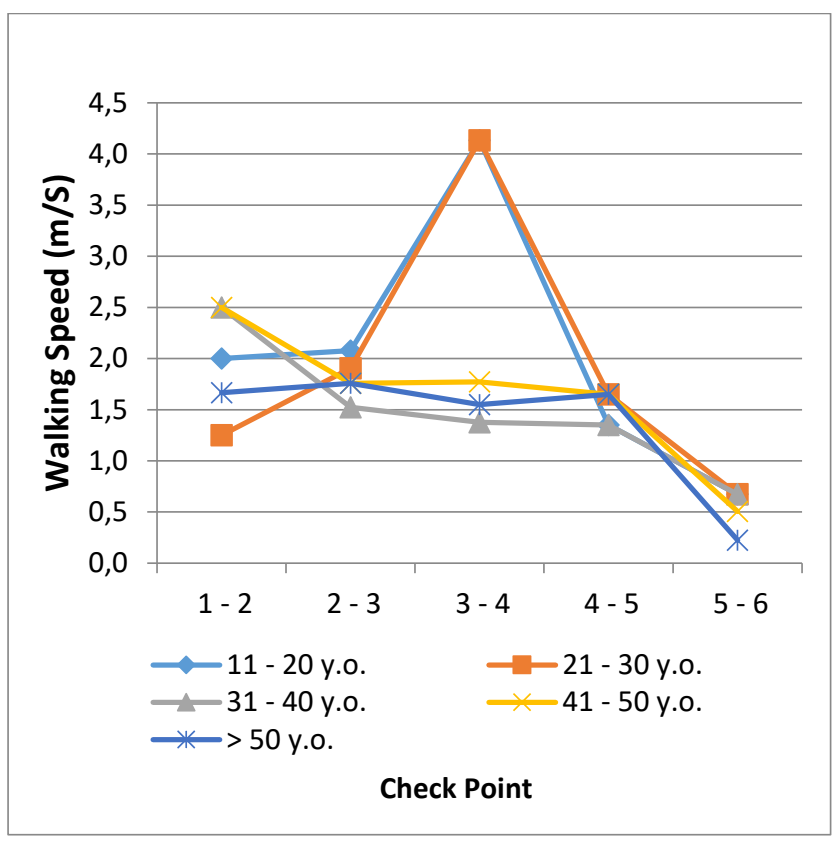

Fig. 5. Walking speed by age interval (through stairs)

\subsection{Ramp}

Walking from the origin point to the destination point at the rooftop of the TES using a ramp will take time as shown in Table 3. Whilst, Fig. 6. shows the walking speed of the evacuees from the origin point through the evacuation route to the destination point (rooftop of the TES) through the available stairs. Fig. 6. shows that in general, the walking speed is reduced by distances. In special cases for the climbing to the rooftop through the ramp, the speed reduced significantly to around 0.075 $\mathrm{m} / \mathrm{s}$. 
Tabel 3. Walking Time Through Ramp by Age Interval Group in Second

\begin{tabular}{|c|c|c|c|c|c|c|c|}
\hline \multirow{2}{*}{$\begin{array}{c}\text { Chec } \\
k \\
\text { Point }\end{array}$} & \multirow[b]{2}{*}{$\begin{array}{l}\text { Distan } \\
\text { ce }(m)\end{array}$} & \multicolumn{6}{|c|}{$\begin{array}{l}\text { Walking Time by Age Group Interval } \\
\text { (Second) }\end{array}$} \\
\hline & & $\begin{array}{c}11- \\
20 \\
\text { y.o. }\end{array}$ & $\begin{array}{c}21- \\
30 \\
\text { y.o. }\end{array}$ & $\begin{array}{c}31- \\
40 \\
\text { y.o. }\end{array}$ & $\begin{array}{c}41- \\
50 \\
\text { y.o. }\end{array}$ & $\begin{array}{l}\text { > } 50 \\
\text { y.o. }\end{array}$ & Av. \\
\hline $1-2$ & 200 & 80 & 120 & 120 & 120 & 120 & 112 \\
\hline $2-3$ & 457 & 240 & 340 & 280 & 280 & 340 & 296 \\
\hline $3-4$ & 248 & 80 & 280 & 120 & 260 & 180 & 184 \\
\hline $4-5$ & 320 & 160 & 180 & 140 & 220 & 200 & 180 \\
\hline $5-6$ & 20 & 140 & 180 & 220 & 200 & 280 & 204 \\
\hline Total & 1245 & & & & & & \\
\hline
\end{tabular}

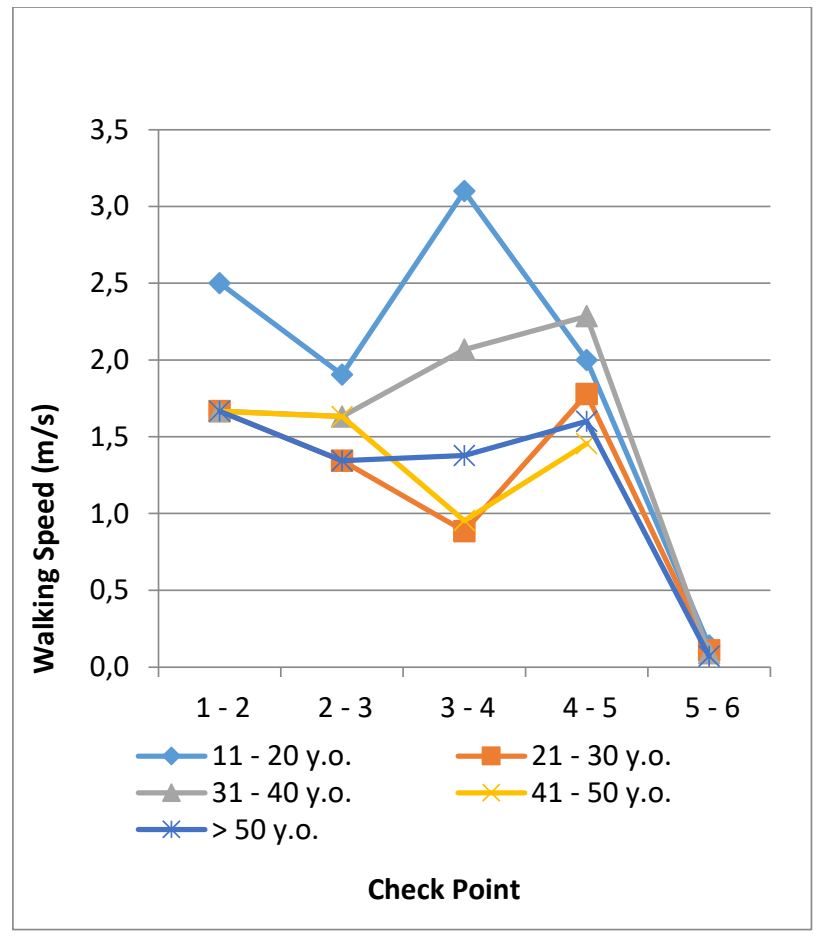

Fig. 6. Walking speed by age interval (through ramp)

\section{Discussion}

Figs. 5 and 6 show that the walking speed of the evacuees was reduced by the distance. However, the walking speed at segment 3 (from checkpoint 3 to 4) is more variable than at other segments. The authors expected that the variation was caused by the traffic and side frictions between parked cars, pedestrians, and unmotorised vehicles along the segment. The characteristics of the segments were not the same. Segment 1 (checkpoints 1 to 2 ) is a local road in the residential area which is typically low traffic and low side friction. Segment 2 (checkpoints 2 to 3 ) is a major road with a sidewalk on both sides of the road. Segment 4 (checkpoints 4 to 5) at the time of the evacuation drill was relatively quiet (very low traffic and pedestrian). Segment 5 (from checkpoint 5 to 6 ) is a segment where the evacuees climb the stair or ramp to reach the rooftop of the TES. Therefore, all of the evacuees should be aware that segment 3 is more unpredictable than other segments which potentially to prevents the evacuees to reach the safe area before the tsunami is coming. An alternative route should be considered in future studies.

Comparing data from Table 2 and Table 3, the walking time from the ground to the top is much higher using a ramp than stairs. This is because the total distance walked is shorter for the stairs than the ramp. Similarly, the speed is much higher when using the stairs than the ramp as shown in Figs 5 and 6. Therefore, it is recommended to use the stairs for those who can climb the stairs. However, for those who cannot easily climb the stair, using a ramp is recommended even though the distance is longer than using stairs.

\section{Conclusion}

A series of evacuation drills had been made in this study to compare the walking speed of evacuees from the origin point to the destination of evacuation which was the rooftop of the temporary evacuation site (TES). The results of the study indicated that the evacuation would be faster when using the stairs than using the ramp. However, the results should be used with caution that the slope of the stair and the ramp in this study are not the same and the time recorded by the observers are in minutes. A more detailed study is recommended to obtain more accurate data and conclusions.

The authors thank the Civil Engineering Department of Andalas University for the funding of this publication under contract number: 120/UN16.09.D/PL/2021.

\section{References}

1. J. C. Borrero, K. Sieh, M. Chlieh, and Synolakis, C. E. P. Natl. Acad. Sci. USA, 103. (2006).

2. R. McCaffrey, Science, 315, (2007).

3. J. McCloskey, A. Antonioli, A. Piatanesi, K. Sieh, S. Steacy, S. Nalbant, M. Cocco, C. Giunchi, J. D. Huang, and P. Dunlop E \& PSc. Lt., 265, Issues 12 (2008)

4. T. Schlurmann, W. Kongko, N. Goserberg, , D.H. K. Natawidjaja, and Sieh, Coastal Engineering. (2010)

5. J. D. Griffin, I. R. Pranantyo, W. Kongko, A. Haunan, R. Robiana, V. Miller, et al. . Indonesia: Earth Science for Disaster Risk Reduction, eds P. R. Cummins and I. Meilano (London: Geological Society). 441 (2016)

6. Yosritzal, BM Kemal, Purnawan, H. Putra IOP Conf. Series: E.E.S. 140 (2018)

7. V. Cedillos, B. G. McAdoo, A. Muhari, and D. H. Natawidjaja. Proceedings of the 9th U.S. National and 10th Canadian Conference on Earthquake Engineering Juli 25-29 (2010)

8. A. Muhammad, K. Goda , N. A. Alexander, W. Kongko, and A. Muhari Nat. Hazards Earth Syst. Sci., 17, (2017) 
9. Yosritzal, B. K. Kemal, and F. Siddik . Proceeding of National Conference of Applied Sciences, Engineering, Business, and Information Technology (2016).

10. Yosritzal,B. K. Kemal, and Y. B. Aulia IJASEITInternational Journal of Advanced Science Engineering Information Technology, (2017)

11. E Mas, F Imamura, S. Koshimura JSCE, (2011).

12. Kim, Nam-Sook. IJST 9 (40) (2016)

13. M. Seike, N. Kawabata, M. Hasegawa, and Y. Lu. (2016)

14. J. Kiyono. and N. Mori,. 13 ${ }^{\text {th }}$ World Conference on Earth Engineering, Vancouver, B.C., Canada. (2013).

15. Yosritzal, H. Putra, Kemal., E. Mas, Purnawan Adv. i.n Eng Res 193 (2020)

16. BPS (2021)

17. BPBD (2010)

18. Stanford Final Report Stanford University (2009).

19. E. Mas, B. Adriano, S. Koshimura, F. Imamura , J.H. Kuroiwa,F. Yamazaki ,C. Zavala , and Estrada M. Book Chapter, Tsunami Events and Lessons Learned 35 (2014).

20. Tribunews (2016).
21. A. Muhammad, R. De Risi, F. De Luca, N. Mori, T. Yasuda, and Goda K. SERRA, 35, (2021).

22. M. S. Sharifi, K. Christensen, A .Chen, D. Stuart, Y. S Kim and Y. Q. Chen Travel Behaviour and Society 8, (2017).

23. M. Iryo-Asano and Alhajyaseen Transportation Research Procedia 21 (2017).

24. E. Bosina and U.Weidmann Physica A 4682017.

25. Paschalidis B Politis I, Basbas S, and Lambrianidou P. Transportation Research Part F 42, (2016)

26. S. Chandra and A. K. Bharti, "Speed distribution curves for pedestrian during walking and crossing", Procedia-Social and Behavioral Sciences 104 (2013) 660-667, (2013).

27. B. M. Kemal, Yosritzal, Y. B. Aulia. IJCIET 2017.

28. M. S. B. H. Abustan. Dissertation at Kyoto University Japan, (2013).

29. N. Wood J, Jones, Schmidtlein M, Schelling J, and Frazier T. IJDRR 18 (2016).

30. F. Chasanah, H. Sakakibara Journal of Integrated Disaster Risk Management, 10 (2). (2020)

31. S. Kubisch, G. J.uth, , S. Keller, M.T. Bull, , Keller, L. and Braun, A.Ch. IJDRR 45 (2020) 